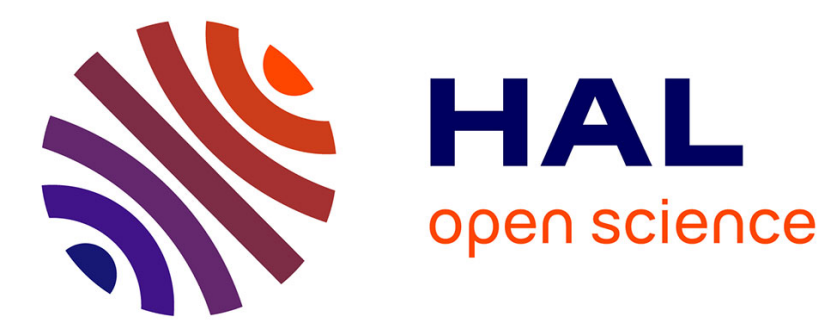

\title{
Applications of Lanthanide Trichloride Hydrates Prepared from Mischmetall in Luche-Type Reduction
}

\author{
Marie-Isabelle Lannou, Florence Hélion, Jean-Louis Namy
}

\section{To cite this version:}

Marie-Isabelle Lannou, Florence Hélion, Jean-Louis Namy. Applications of Lanthanide Trichloride Hydrates Prepared from Mischmetall in Luche-Type Reduction. SYNLETT, 2007, 2007 (17), pp.27072710. 10.1055/s-2007-991062 . hal-02371227

\section{HAL Id: hal-02371227 \\ https://hal.science/hal-02371227}

Submitted on 8 Oct 2021

HAL is a multi-disciplinary open access archive for the deposit and dissemination of scientific research documents, whether they are published or not. The documents may come from teaching and research institutions in France or abroad, or from public or private research centers.
L'archive ouverte pluridisciplinaire HAL, est destinée au dépôt et à la diffusion de documents scientifiques de niveau recherche, publiés ou non, émanant des établissements d'enseignement et de recherche français ou étrangers, des laboratoires publics ou privés. 


\title{
Applications of Lanthanide Trichloride Hydrates Prepared from Mischmetall in Luche-Type Reduction
}

\author{
Marie-Isabelle Lannou, Florence Hélion, Jean-Louis Namy* \\ Laboratoire de Catalyse Moléculaire, ICMMO, Bât 420, Université Paris-Sud, 91405, Orsay, France \\ Fax+33(1)69154680; E-mail: flohelion@icmo.u-psud.fr
}

\begin{abstract}
An inexpensive alloy of light lanthanides, called Mischmetall, has been used in the preparation of a mixture of lanthanide trichloride hydrates. The use of this new type of material is described in Luche-type reductions.
\end{abstract}

Key words: Mischmetall, lanthanide trichlorides, Luche-type reaction

Over the past three decades, lanthanides have been widely used in organic synthesis, showing good reactivity as reactants but also as catalysts. In this field, very efficient chiral complexes have recently been developed. Thanks to their physical and chemical properties, many lanthanides exhibit a similar behavior in organic reactions. Since they are available as a mixture in ores (bastnaesite, monazite), it seems obvious that they could be used in organic synthesis in this way. However, this interesting property has not been taken into account so far, which is somewhat illogical since separation of elements is the expensive process in the treatment of ores. Since $1999^{1 \mathrm{a}}$ our group has been interested in the use of an alloy of light lanthanides, called Mischmetall, obtained from bastnaesite. Our approach relies upon the will to develop the use of a particularly low-cost material in comparison with separated lanthanide metals.

Mischmetall is an alloy of light lanthanides about ten times cheaper than cerium and whose composition is roughly: cerium $(48-50 \%)$, lanthanum (32-34\%), praseodymium (13-14\%), neodymium (4-5\%), and other rare-earth metals $(1-2 \%)$. So far, we have described the use of Mischmetall as a co-reductant for samarium diiodide $^{1}$ and also the use of its anhydrous trivalent derivatives in reactions involving stoichiometric amounts of lanthanide salts (Luche- and Imamoto-type reaction). In addition, those lanthanide salts have been used in reactions such as Meerwein-Pondorff-Verley reduction, Oppenauer oxidation or Mukaiyama-aldol-type reaction. ${ }^{2}$

Here we wish to report a simple method for the preparation of a mixture of lanthanide trichloride hydrates directly from Mischmetall and its use in organic reactions. We investigated the reactivity of this new material and compared it to the reactivity of classically used trichloride hydrates derived from pure lanthanide metals. Stoichio- metric amounts of Mischmetall trichloride hydrates were involved in Luche-type reduction to prepare allylic alcohols or allyl alkyl ethers.

Lanthanide trihalide hydrates are commercially available or can easily be prepared by refluxing in water lanthanide oxides or lanthanide metals ingots with halohydric acids (Scheme 1). ${ }^{3,4}$ Lanthanide oxides are more currently used since they are cheaper and insensitive to oxidation, contrary to the corresponding metals. However, metals are far more reactive.

$$
\begin{aligned}
& \underset{\text { (excess) }}{2 \mathrm{Ln}_{2} \mathrm{O}_{3}+3 \mathrm{HX}} \frac{\mathrm{H}_{2} \mathrm{O}, 100{ }^{\circ} \mathrm{C}, 1 \mathrm{~h}}{\text { then r.t., } 12 \mathrm{~h}} 2 \mathrm{LnX}_{3} \cdot \mathrm{nH}_{2} \mathrm{O} \\
& \mathrm{X}=\mathrm{Cl}, \mathrm{Br}, \mathrm{I}
\end{aligned}
$$

Scheme 1 Typical synthesis of lanthanide trihalide hydrates

Lanthanide trichloride hydrates were prepared in a onestep procedure using an excess of Mischmetall ingots in water. The procedure is similar to that described above, involving separated lanthanide oxides (Scheme 1). However, in contrast with lanthanide metals, Mischmetall reacts slowly with atmospheric oxygen; thus, it is much easier to handle than separated lanthanide metals. Moreover, it is more reactive than lanthanide oxides; thus, the reaction with hydrochloric acid is faster and can be conducted at room temperature. The mixture of lanthanide trichloride hydrates $\left(\mathrm{LnCl}_{3} \cdot 7 \mathrm{H}_{2} \mathrm{O}\right)$ is obtained in excellent yield (Scheme 2).

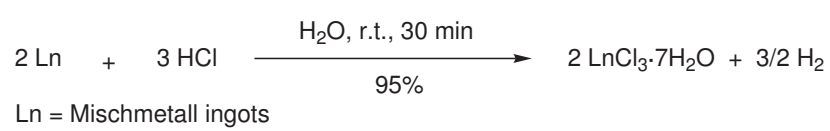

Scheme 2 Synthesis of lanthanide trichloride hydrates from Mischmetall ingots

This material is quite stable towards atmospheric oxygen and can be stored without special care.

Since the end of the seventies, the Luche-type reduction has proved to be a very versatile tool in organic synthesis. ${ }^{5}$ The Luche reagent $\left(\mathrm{NaBH}_{4} / \mathrm{CeCl}_{3} \cdot 7 \mathrm{H}_{2} \mathrm{O}\right.$ in methanolic solution) allows the regioselective 1,2-reduction of enones; thus, providing allylic alcohols in excellent yields. 
The reactivity of 'Mischmetall trichlorides' was evaluated in Luche-type reactions on a variety of $\alpha, \beta$-unsaturated ketones. Reaction conditions are similar to the original Luche procedure. ${ }^{5}$ However, this work has also shown the importance of $\mathrm{pH}$ control during the hydrolysis step. Actually, depending on the workup conditions, an allyl methyl ether can be obtained instead of the expected allylic alcohol (Scheme 3).

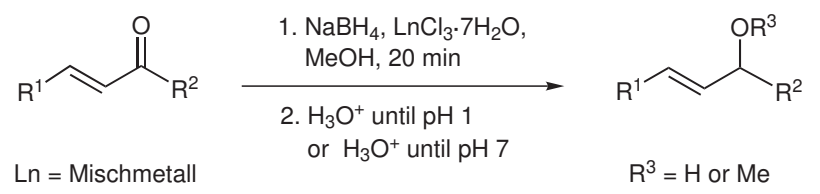

Scheme 3 Luche-type reduction involving lanthanide trichlorides

The results are collected in Table 1. Hydrated lanthanide trichlorides synthesized from Mischmetall allowed us to prepare allylic alcohols in fairly good yields (entries 1, 3, 6 , and 8), when hydrolysis was conducted under neutral conditions, an $\alpha, \beta$-unsaturated diketone (entry 5 ) was also reduced in quantitative yield. However, in specific cases, hydrolysis of the reaction mixture under stronger acidic conditions allowed the formation of allyl methyl ethers. Ethers were exclusively formed in reactions involving benzylidene acetone (entry 2), chalcone (entry 4), and $\beta$ ionone (entry 7). However, when $\alpha$-ionone was used, the allylic alcohol was formed exclusively (entries 8 and 9). We checked that the formation of allyl methyl ethers was not due to the presence of Mischmetall salts, since using hydrated cerium trichloride led to a similar distribution of products. ${ }^{6}$ The formation of saturated alcohols or ethers from enones was never observed, thus proving that the Luche-type reduction induced by Mischmetall salts is $100 \%$ regioselective in 1,2-positions. At first glance, our results seem surprising, since Luche reported in his initial publication that the hydrolysis of the cerium trichloride induced sodium borohydride reduction of enones can be conducted in a wide range of $\mathrm{pH} .{ }^{5 \mathrm{~b}}$ However, the authors did not report results for the reduction of ketones, where the enone moiety is conjugated with another unsaturated system.

In order to rationalize our results and to gain insight into the mechanism of this reaction, the Luche-type reduction of acetophenone was studied: the hydrolysis was conducted under acidic and neutral conditions. In both cases, only 1-phenylethanol was obtained in excellent yields $(98 \%$ and $88 \%$, respectively), proving that the presence of the $\mathrm{C}=\mathrm{C}$ double bond conjugated to the aromatic ring is crucial for the formation of the methyl ether. As further evidence, the results obtained with $\alpha$ - and $\beta$-ionone show that the conjugation of the enone moiety to a $\mathrm{C}=\mathrm{C}$ double bond is necessary for the ether formation.

Simple tests were carried out by using benzylidene acetone as a substrate. As described above, neutral workup of the reaction provided selectively allylic alcohol 1a and strong acidic workup ( $\mathrm{pH} 1)$ provided selectively allyl
Table 1 Luche-Type Reduction of $\alpha, \beta$-Unsaturated Ketones

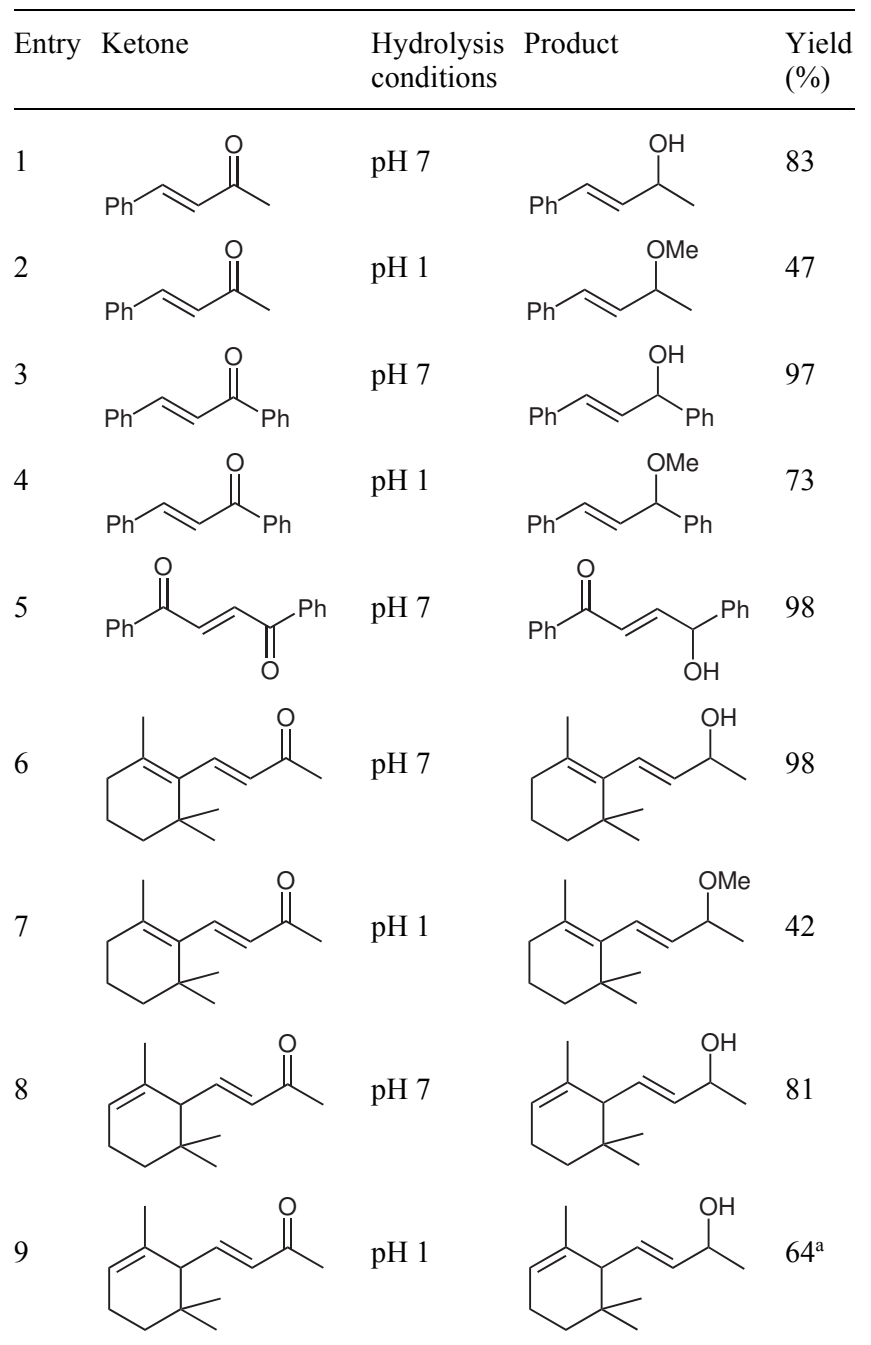

${ }^{a}$ Methyl ether is not formed at $\mathrm{pH} 1$.

methyl ether 1b. Mild acidic workup ( $\mathrm{pH} 3$ ) gave a 35:65 mixture of $\mathbf{1 a}$ and $\mathbf{1 b}$ (Scheme 4). These results show that the distribution of the products depends on the $\mathrm{pH}$.

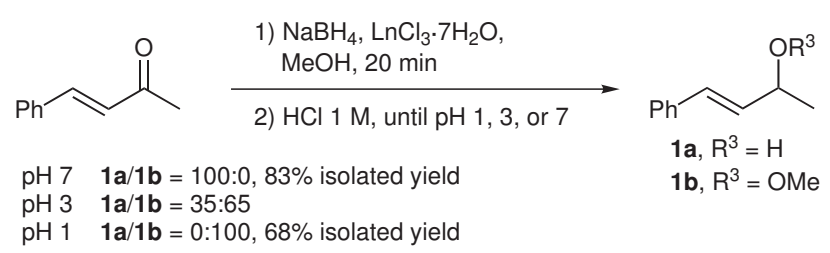

Scheme 4 Influence of $\mathrm{pH}$ upon reduction of benzylidene acetone

Then 1,3-diphenylprop-2-enol was mixed with methanol, and the solution was adjusted to $\mathrm{pH} 1$ with $1 \mathrm{M}$ hydrochloric acid. Corresponding allyl methyl ether was formed in good yield under these reaction conditions. This method could easily be extended to other primary and secondary alcohols (Scheme 5). These results show that lanthanides (or boron salts) are not responsible for the formation of 
allyl alkyl ethers under acidic workup conditions. Their formation is only ascribable to the acidity of the media. However, in this field, the formation of allylic ethers as byproducts upon acidic catalysis is frequently observed with aromatic enones, though rather poorly documented. ${ }^{7}$

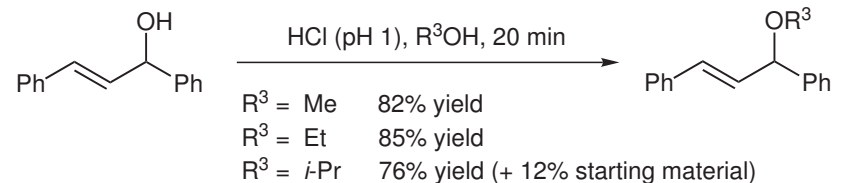

Scheme 5 Synthesis of various allyl alkyl ethers upon acidic hydrolysis

In 1999 Barluenga et al. ${ }^{8}$ described a similar phenomenon in the Luche-type reduction of divinylketones. Acidic workup of the reaction mixture gave an $E, E$-dienyl ethyl ether formed by the recombination of the intermediate carbocation. Considering our work (Scheme 5) in the light of Barluenga's study, led us to suggest a mechanistic scheme involving a carbocation, where the etherification reaction occurs selectively in cases where the carbocation is stabilized, namely when the $\mathrm{C}=\mathrm{C}$ double bond is conjugated to another unsaturation (aromatic ring, $\mathrm{C}=\mathrm{C}$ double bond).

Mischmetall trichloride hydrates were synthesized in a one-step procedure from the inexpensive alloy Mischmetall in order to be tested in a classical organic reaction. These complexes exhibited the same reactivity as cerium trichloride in the sodium borohydride reduction of highly conjugated ketones (Luche-type reduction). In addition, we described conditions for easy access to allyl methyl ethers, using acidic hydrolysis conditions.

This example is the first application of Mischmetall trichloride hydrates in organic synthesis. Obviously, the use of this material could be extended to a wide variety of reactions involving lanthanide salts.

Typical Experimental Procedure for Synthesis of $\mathrm{LnCl}_{3}$ In a two-necked flask fitted with a reflux condenser and a dropping funnel ingots of Mischmetall ( $4 \mathrm{~g}, 28.6 \mathrm{mmol}$ ), were placed in $\mathrm{H}_{2} \mathrm{O}$ $(20 \mathrm{~mL})$. Then, $6 \mathrm{M} \mathrm{HCl}(9.6 \mathrm{~mL}, 57.3 \mathrm{mmol})$ was added dropwise under stirring. A rise temperature was observed together with a gas evolution. After $30 \mathrm{~min}, \mathrm{pH}$ must be neutral. The solution was then filtered off in order to eliminate the excess of Mischmetall, then the filtrate was distilled to eliminate $\mathrm{H}_{2} \mathrm{O}$ and evaporation was completed with the rotatory evaporator. Mischmetall trichloride hydrates were dried for $12 \mathrm{~h}$ under primary vacuum to give $\mathrm{LnCl}_{3} \cdot 7 \mathrm{H}_{2} \mathrm{O}$ $(\mathrm{m}=6.75 \mathrm{~g}, 95 \%$ yield $)$.

\section{Typical Experimental Procedure for Luche-Type Reduction}

Mischmetall trichloride (373 mg, $1 \mathrm{mmol}$ ) was placed in $\mathrm{MeOH}$ $(2.5 \mathrm{~mL})$ in a $10 \mathrm{~mL}$ flask. Ketone $(1 \mathrm{mmol})$ was added under stirring at $0{ }^{\circ} \mathrm{C}$. Sodium borohydride $(57 \mathrm{mg}, 1.5 \mathrm{mmol})$ was added portionwise, then the reaction mixture was stirred for another 15 $\min$ at r.t.

\section{Workup Conditions (pH 7)}

The reaction mixture was treated by a decimolar solution of $\mathrm{HCl}$ until $\mathrm{pH} 7$, then extracted three times with $\mathrm{Et}_{2} \mathrm{O}$. Combined organic layers were washed with brine, then dried over $\mathrm{MgSO}_{4}$. Solvents were evaporated, then the crude product was purified by flash chromatography over silica gel.

\section{Workup Conditions (pH 1)}

The reaction mixture was treated by a $1 \mathrm{M}$ solution of $\mathrm{HCl}$ until $\mathrm{pH}$ 1 , then extracted three times with $\mathrm{Et}_{2} \mathrm{O}$. Combined organic layers were washed with brine, then dried over $\mathrm{MgSO}_{4}$. Solvents were evaporated, then crude product was purified by flash chromatography over silica gel.

\section{Selected Spectral Data}

(E)-4-(2,6,6-Trimethylcyclohex-1-enyl)-but-3-en-2-ol Obtained Under Workup Conditions A

${ }^{1} \mathrm{H}$ NMR $\left(250 \mathrm{MHz}, \mathrm{CDCl}_{3}\right): \delta=0.91\left[6 \mathrm{H}, \mathrm{s}, \mathrm{C}\left(6^{\prime}\right)\left(\mathrm{CH}_{3}\right)_{2}\right], 1.11-$ $1.71\left[4 \mathrm{H}, \mathrm{m}, \mathrm{C}\left(4^{\prime}\right) \mathrm{H}_{2}, \mathrm{C}\left(5^{\prime}\right) \mathrm{H}_{2}\right], 1.22\left[3 \mathrm{H}, \mathrm{d}, \mathrm{C}(1) \mathrm{H}_{3}, J_{1-2}=6.4\right.$ $\mathrm{Hz}$ ], 1.59 [3 H, s, C(2') $\mathrm{CH}_{3}$ ], 1.90 [2 H, t, C(3') $\left.\mathrm{H}_{2}, J_{3^{\prime}-4^{\prime}}=6.4 \mathrm{~Hz}\right]$, $2.16\left[1 \mathrm{H}, \mathrm{d}, \mathrm{C}(2) \mathrm{OH}, J_{\mathrm{OH}-2}=7.3 \mathrm{~Hz}\right], 4.28[1 \mathrm{H}, \mathrm{m}, \mathrm{C}(2) \mathrm{H}], 5.40$ $\left[1 \mathrm{H}, \mathrm{dd}, \mathrm{C}(3) \mathrm{H}, J_{3-4}=16.1 \mathrm{~Hz}, J_{3-2}=6.4 \mathrm{~Hz}\right], 5.95[1 \mathrm{H}, \mathrm{d}, \mathrm{C}(4) \mathrm{H}$, $\left.J_{4-3}=16.1 \mathrm{~Hz}\right] \mathrm{ppm} .{ }^{13} \mathrm{C} \mathrm{NMR}\left(62.9 \mathrm{MHz}, \mathrm{CDCl}_{3}\right): \delta=19.1,21.3$, $23.5,28.6,32.6,33.8,39.3,69.3,127.2,128.5,136.6,137.7 \mathrm{ppm}$. FTIR $\left(\mathrm{CaF}_{2}\right): v_{\max }=3339,2965,2928,2865,2828,1456,1371$, $1360,1336,1287,1204,1145,1058 \mathrm{~cm}^{-1}$. GC-MS (IE): $\mathrm{m} / z(\%$ base peak $=194(13), 179(20), 176(11), 161(44), 136(29), 123$ (31), 121 (95), 119 (34), 109 (30), 107 (27), 105 (38), 95 (42), 93 (53), 91 (43), 81 (36), 79 (35), 77 (28), 69 (34), 67 (22), 55 (40), 53 (19), 43 (100), 41 (54), 39 (16).

\section{2-[(E)-3-Methoxybut-1-enyl]-1,3,3-trimethylcyclohexene} Obtained Under Workup Conditions B

${ }^{1} \mathrm{H}$ NMR $\left(250 \mathrm{MHz}, \mathrm{CDCl}_{3}\right): \delta=0.98\left[6 \mathrm{H}, \mathrm{s}, \mathrm{C}(3)\left(\mathrm{CH}_{3}\right)_{2}\right], 1.25[3$ $\left.\mathrm{H}, \mathrm{d}, \mathrm{C}\left(4^{\prime}\right) \mathrm{H}_{3}, J_{4^{\prime}-3^{\prime}}=6.4 \mathrm{~Hz}\right], 1.64-1.36\left[4 \mathrm{H}, \mathrm{m}, \mathrm{C}(4) \mathrm{H}_{2}, \mathrm{C}(5) \mathrm{H}_{2}\right]$, $1.66\left[3 \mathrm{H}, \mathrm{s}, \mathrm{C}(1) \mathrm{CH}_{3}\right], 1.96\left[2 \mathrm{H}, \mathrm{t}, \mathrm{C}(6) \mathrm{H}_{2}, J_{6-5}=6.1 \mathrm{~Hz}\right], 3.28[3$ $\left.\mathrm{H}, \mathrm{s}, \mathrm{C}\left(3^{\prime}\right) \mathrm{OCH}_{3}\right], 3.73\left[1 \mathrm{H}, \mathrm{dq}, \mathrm{C}\left(3^{\prime}\right) \mathrm{H}, J_{3^{\prime}-2^{\prime}}=7.8 \mathrm{~Hz}, J_{3^{\prime}-4^{\prime}}=6.4\right.$ $\mathrm{Hz}$ ], $5.25\left[1 \mathrm{H}, \mathrm{dd}, \mathrm{C}\left(2^{\prime}\right) \mathrm{H}, J_{2^{\prime}-1^{\prime}}=15.6 \mathrm{~Hz}, J_{2^{\prime}-3^{\prime}}=7.8 \mathrm{~Hz}\right.$ ], $5.99[1$ $\left.\mathrm{H}, \mathrm{d}, \mathrm{C}\left(1^{\prime}\right) \mathrm{H}, J_{1^{\prime}-2^{\prime}}=15.6 \mathrm{~Hz}\right] \mathrm{ppm} .{ }^{13} \mathrm{C} \mathrm{NMR}\left(62.9 \mathrm{MHz}, \mathrm{CDCl}_{3}\right)$ : $\delta=19.2,21.4,21.9,28.7,32.6,33.8,39.3,55.9,78.8,128.7,129.9$, 135.4, 136.8 ppm. FTIR $\left(\mathrm{CaF}_{2}\right): v_{\max }=2968,2928,2860,2825$, 2109, 1733, 1458, 1371, 1260. GC-MS (IE): $\mathrm{m} / \mathrm{z}$ (\% base peak) = $208(64), 193(39), 176(7), 161(80), 151(10), 137$ (24), 133 (26), 121 (26), 107 (31), 106 (23), 105 (60), 95 (15), 93 (29), 91 (46), 85 (28), 79 (23), 77 (23), 69 (22), 59 (100), 55 (29), 43 (28), $41(33)$.

\section{Acknowledgment}

We thank the University of Paris-Sud and CNRS for their financial support.

\section{References}

(1) (a) Hélion, F.; Namy, J.-L. J. Org. Chem. 1999, 64, 2944. (b) di Scala, A.; Garbacia, S.; Hélion, F.; Lannou, M.-I.; Namy, J.-L. Eur. J. Org. Chem. 2002, 2989. (c) Lannou, M.-I.; Helion, F.; Namy, J.-L. Tetrahedron Lett. 2002, 43, 8007.

(2) Lannou, M.-I.; Hélion, F.; Namy, J.-L. Tetrahedron 2003, $53,10551$. 
(3) (a) Herrmann, W. A.; Brauer, G. In Synthetic Methods of Organometallic and Inorganic Chemistry, Vol. 6; Thieme Verlag: Stuttgart / New York, 1997, 2. (b) Herrmann, W. A.; Brauer, G. In Synthetic Methods of Organometallic and Inorganic Chemistry, Vol. 6; Thieme Verlag: Stuttgart / New York, 1997, 32.

(4) Brown, D.; Fletcher, S.; Holah, D. G. J. Chem. Soc. A 1968, 1889.

(5) (a) Luche, J.-L. J. Am. Chem. Soc. 1978, 100, 2226.

(b) Luche, J.-L.; Rodriguez-Hahn, L.; Crabbe, P. J. Chem. Soc., Chem. Commun. 1978, 601. (c) Gemal, A. L.; Luche, J.-L. J. Am. Chem. Soc. 1979, 101, 5848.
(6) Voituriez, A. PhD Thesis; University Paris XI: Orsay, 2004.

(7) (a) Ito, S.; Matsumoto, M. Synth. Commun. 1982, 12, 807. (b) Iranpoor, N.; Mothaghinegad, E. Tetrahedron 1994, 50, 1859. (c) Gadhwal, S.; Bomah, A.; Prajapati, D.; Sandhu, J. Synth. Commun. 1999, 11, 1921. (d) Ooi, T.; Ichitawa, H.; Itagaki, Y.; Maruoka, K. Heterocycles 2000, 52, 575.

(8) Barluenga, J.; Fañanás, F. J.; Sanz, R.; Garcia, F.; Garcia, N. Tetrahedron Lett. 1999, 40, 4735. 